\title{
Pemberian Pupuk Fosfat dan Fungi Mikoriza Arbuskular terhadap Pertumbuhan Tanaman Legum Pohon (Indigofera zollingeriana)
}

\author{
Phosphate Fertilizer and Arbuscular Mycorrhiza Fungi on the Growth of Legumes Tree \\ (Indigofera zollingeriana)
}

\author{
J. Laksono dan T. Karyono
}

Fakultas Pertanian Prodi Peternakan Universitas Musi Rawas

Jl. Komplek perkantoran pemkab MURA Kel. Air kuti I. Lubuklinggau 31628

e-mail: judolaksono@gmail.co.id

\begin{abstract}
The purpose of this research was to determine the growth of the tree legume Indigofera against phosphate fertilizer and mycorrhizal fungi. The method used is to use a completely randomized design (CRD) factorial with 2 factors and 3 replications. Mycorrhizal fungi as the first factor is the level of administration M0: Without Mycorrhizae, M1: 5 gr Mycorrhizae / polybag, M2: 10 gr Mycorrhizae / polybag. The second factor is phosphate-treated, P0: Without Fertilizers, P1: Rock Phosphate Fertilizer (20\% P2O5) 270kg / ha P2: Fertilizer SP-36 (36\% P2O5) $150 \mathrm{~kg} / \mathrm{ha}$. The results of the study plant growth indigofera treated arbuscular mycorrhizal fungi and fertilizer fospat showed significant $(\mathrm{P}<0.05)$ on plant height, and the effect was not significant $(\mathrm{P}>$ 0.05 ) on stem diameter, number of branches and number of nodules. Zolligeriana Indigofera plant growth by $\mathrm{P} 2$ phosphate fertilizers: Fertilizers SP-36 (36\% P2O5) $150 \mathrm{~kg} /$ ha and mycorrhizal fungi inoculation M2: $10 \mathrm{gr}$ Mycorrhizae / polybag showed best results on plant height parameters.
\end{abstract}

Key words: Mycorrhiza, phosphate fertilizer, Indigofera, rock phosphate

\begin{abstract}
ABSTRAK
Tujuan dari penelitan ini adalah untuk mengetahui pertumbuhan legum pohon Indigofera terhadap pemberian pupuk fosfat dan fungi mikoriza. Metode penelitian yang digunakan adalah dengan menggunakan Rancangan Acak Lengkap (RAL) pola faktorial dengan 2 faktor perlakuan dan 3 kali ulangan. Faktor pertama adalah fungi mikoriza dengan level pemberian M0 : Tanpa Mikoriza, M1 : 5 gr Mikoriza / polybag, M2 : 10 gr Mikoriza/ polybag. Faktor kedua fosfat dengan perlakuan, P0 : Tanpa Pupuk, P1 : Pupuk Rock Fosfat $\left(20 \% \mathrm{P}_{2} \mathrm{O}_{5}\right) 270 \mathrm{~kg} / \mathrm{ha}$ P2 : Pupuk SP-36 $\left(36 \% \mathrm{P}_{2} \mathrm{O}_{5}\right) 150 \mathrm{~kg} / \mathrm{ha}$. Hasil penelitian pertumbuhan tanaman indigofera yang diberi perlakuan fungi mikoriza arbuskular dan pupuk fospat menunjukan berpengaruh nyata $(\mathrm{P}<0,05)$ terhadap tinggi tanaman, serta berpengaruh tidak nyata $(\mathrm{P}>0,05)$ terhadap diameter batang, jumlah cabang dan jumlah nodul. Pertumbuhan tanaman Indigofera zolligeriana yang diberi pupuk fosfat P2 : Pupuk SP-36 $\left(36 \% \mathrm{P}_{2} \mathrm{O}_{5}\right) 150 \mathrm{~kg} / \mathrm{ha}$ dan Inokulasi fungi mikoriza M2 :10 gr Mikoriza/ polybag memberikan hasil terbaik pada parameter tinggi tanaman.
\end{abstract}

Kata kunci: Mikoriza, pupuk fosfat, Indigofera, rock pospat

\section{PENDAHULUAN}

Pengembangan ternak ruminansia dapat berjalan dengan baik jika kebutuhan akan hijauan pakan tersedia. Penyediaan pakan secara berkelanjutan dalam arti jumlah yang cukup dan kualitas yang baik merupakan salah satu faktor yang sangat mempengaruhi produktivitas ternak ruminansia. Legum pohon sebagai tanaman pakan di daerah tropis memegang peranan penting dalam penyediaan pakan hijauan yang bergizi tinggi. Salah satu legum pohon yang dapat menghasilkan hijauan sepanjang tahun adalah Indigofera Mengingat potensi nutrisi dan produksinya yang cukup baik, maka perlu diupayakan budidaya yang efektif yang dapat meningkatkan pertumbuhan tanaman. Dalam proses budidaya tanaman indigovera peranan yang sangat penting 
adalah pemupukan. Pupuk merupakan upaya meningkatkan ketersediaan nutrisi bagi tanaman yang dapat diserap oleh tanaman maka perlu dilakukan pemupukan yang paling di butuhkan pada tanaman legum yaitu pupu fosfat. Fosfat berperan penting dalam proses pembelahan sel dan perkembangan jaringan meristem (Sutejo dan Mulyani 1999). Menurut Tisdale et al.(1985) fosfat merupakan unsur yang berfungsi dalam proses transfer energi, yang merupakan proses penting bagi pertumbuhan tanaman. Menurut Agustina (2004), fosfat berperan penting dalam transfer energi didalam sel tanaman, pembentukan membran, serta meningkatkan efisiensi dan penggunaan $\mathrm{N}$. Untuk meningkatkan ketersediaan dan serapan fospat alam (P) pada tanaman perlu adanya pupuk hayati.

Salah satu pupuk hayati yang dapat dijadikan sebagai alternatif adalah pupuk hayati fungi mikoriza. Fungi mikoriza mempunyai peranan yang penting dalam pertumbuhan tanaman, fungi mikoriza dapat bersimbiosis dengan akar tanaman. Nuhamara (1994), menyatakan bahwa sedikitnya ada lima hal yang dapat membantu perkembangan tanaman dengan adanya fungi mikoriza, yaitu: fungi mikoriza arbuskular dapat meningkatkan absorpsi hara dari dalam tanah, berperan sebagai penghalang biologi terhadap infeksi patogen akar, meningkatkan ketahanan tanaman terhadap kekeringan yang ekstrim, meningkatkan produksi hormon pertumbuhan dan zat pengatur tumbuh lainnya seperti auksin, dan menjamin terselenggaranya biogeokemis.

\section{MATERI DAN METODE}

Penelitian dilaksanakan di Kebun Percobaan Fakultas Pertanian Universitas Musi Rawas Kelurahan Warterpang Kota Lubuklinggau Timur I Sumatra Selatan, dengan ketinggian tempat 93 meter di atas permukaan laut. Penelitian berlangsung mulai bulan April sampai dengan bulan Juli tahun 2015.

Bahan-bahan yang digunakan dalam penelitian ini adalah: Bibit Indigofera, fungi mikoriza arbuskular, pupuk urea, pupuk Rock Fospat, SP-36 pupuk $\mathrm{KCl}$, polybag ukuran $10 \mathrm{~kg}$, fungisida, kapur pertanian (dolomit) dan bambu. Sedangkan alat-alat yang digunakan adalah: cangkul, parang, sabit, meteran, penggaris, alat tulis, timbangan, ember, selang, alat tulis dan mikroskop.

Penelitian ini dilakukan dengan menggunakan Rancangan Acak Lengkap (RAL) pola faktorial dengan 2 faktor perlakuan dan 3 ulangan. Faktor pertama adalah pupuk fosfat dengan perlakuan : P0 ; Tanpa Pupuk, P1 ; Pupuk Rock Fosfat $\left(20 \% \mathrm{P}_{2} \mathrm{O}_{5}\right)$ 270kg/ha /1,08 gr/polybag, P2 ; Pupuk SP-36 ( $36 \% \mathrm{P}_{2} \mathrm{O}_{5}$ ) $150 \mathrm{~kg} / \mathrm{ha} / 0,6$ gr/polybag. Faktor kedua fungi mikoriza dengan level pemberian : M0 ; Tanpa Mikoriza, M1 ; 5 gr Mikoriza / polybag dan M2 ; 10 gr Mikoriza/ polybag. Setiap unit perlakuan di ulang $3 \mathrm{kali}$, sehingga jumlah keseluruhan unit percobaan sebanyak 27 unit percobaan. 


\section{HASIL DAN PEMBAHASAN}

\section{Pertumbuhan Tanaman}

Pertumbuhan tanaman merupakan suatu proses yang ditandai dengan bertambahnya ukuran dan berat tanaman. Penambahan ini disebabkan oleh bertambahnya organ tanaman seperti tinggi tanaman, diameter daun, jumlah cabang dan jumlah nodul, sebagai akibat dari metabolisme tanaman yang dipengaruhi oleh lingkungan di daerah tempat tumbuh tanaman, seperti suhu, sinar matahari, air, dan nutrisi di dalam tanah (Irdiana et al., 2002).

\section{Tinggi Tanaman $(\mathrm{cm})$}

Hasil analisis ragam menunjukan bahwa pemberian fungi mikoriza arbuskular berpengaruh nyata $(\mathrm{P}<0,05)$ terhadap tinggi tanaman (Tabel 1). Uji lanjut menunjukkan bahwa pemberian fungi mikoriza arbuskular pada M2 berbeda nyata $(\mathrm{P}<0,05)$ dengan $\mathrm{M} 0$ dan berbeda tidak nyata dengan M1. Hal ini diduga karena pemberian 10 gram mikoriza arbuskular M2 merupakan jumlah yang dibutuhkan tanaman Indigofera untuk pertumbuhan tingginya. Sebagaimana dijelaskan oleh Niswati et al.(1996), pemberian 10 gram/ tanaman fungi mikoriza berperan dalam peningkatan pertumbuhan tanaman dengan meningkatkan jalan serapan hara melalui perluasan permukaan areal serapan dan serapan unsur hara dan perkembangan fungi mikoriza dapat juga dipengaruhi oleh jenis tanaman dan tanah.

Tabel 1. Rataan pertumbuhan tanaman Indigofera dari beberapa perlakuan pupuk fosfat dan fungi mikoriza.

\begin{tabular}{lcccc}
\hline \multicolumn{1}{c}{ Perlakuan } & $\begin{array}{c}\text { Tinggi } \\
\text { Tanaman }(\mathrm{cm})\end{array}$ & $\begin{array}{c}\text { Diameter } \\
\text { Batang }(\mathrm{cm})\end{array}$ & $\begin{array}{c}\text { Jumlah } \\
\text { Cabang }\end{array}$ & $\begin{array}{c}\text { Jumlah } \\
\text { Nodul }\end{array}$ \\
\hline Jenis Fospat & & & & \\
P0 & $80,33 \pm 9,37$ & $0,66 \pm 0,05$ & $4,67 \pm 1,32$ & $66,22 \pm 6,76$ \\
P1 & $77,94 \pm 7,16$ & $0,63 \pm 0,07$ & $4,56 \pm 0,42$ & $55,45 \pm 14,77$ \\
P2 & $81,50 \pm 4,32$ & $0,61 \pm 0,07$ & $4,98 \pm 1,36$ & $70,78 \pm 19,13$ \\
& & & & \\
Level Mikoriza & & & & \\
M0 & $74,22 \pm 4,55 \mathrm{a}$ & $0,65 \pm 0,04$ & $4,81 \pm 0,57$ & $56,67 \pm 6,06$ \\
M1 & $81,49 \pm 7,94 \mathrm{ab}$ & $0,59 \pm 0,09$ & $4,67 \pm 1,32$ & $59,00 \pm 17,90$ \\
M2 & $84,05 \pm 3,37 \mathrm{~b}$ & $0,66 \pm 0,03$ & $4,72 \pm 1,35$ & $76,78 \pm 9,80$ \\
\hline
\end{tabular}

Keterangan : Angka-angka yang diikuti oleh huruf yang sama pada setiap kolom menunjukan perbedaan tidak nyata pada taraf 5\% Uji Berganda Duncan

Selain itu, pemberian 10 gram mikoriza/tanaman dapat meningkatkan kemampuan hifa eksternal mikoriza dalam membantu akar untuk menyerap unsur hara, sehingga unsur hara yang diserap oleh akar tanaman akan dimanfaatkan untuk memacu proses fotosintesis di daun. Menurut Gardner et al. (1991), hasil fotosintesis tersebut akan ditranslokasikan ke seluruh bagian tanaman untuk pertumbuhan dan perkembangan tanaman. Hifa eksternal dari jamur mikoriza dapat meningkatkan 
zona penyerapan pada daerah rizosfer, sehingga pasokan hara menjadi lebih baik (Simarmata 2005).

Hasil analisis ragam interaksi menunjukan bahwa pemberian pupuk fosfat berpengaruh tidak nyata ( $\mathrm{P}>0,05)$ terhadap parameter tinggi tanaman. Hal ini diduga karena pada saat pertumbuhan vegetatif tanaman Indigofera lebih dipengaruhi oleh ketersediaan unsur $\mathrm{N}$. Sebagaimana dijelaskan oleh Novizan (2002), unsur N pada tanaman berfungsi membentuk asam amino dan protein yang dimanfaatkan dalam memacu pertumbuhan fase vegetatif.

\section{Diameter Batang (cm)}

Hasil analisis ragam menunjukan bahwa pemberian pupuk fosfat dan fungi mikoriza arbuskular berpengaruh tidak nyata $(\mathrm{P}>0,05)$ terhadap parameter diameter batang (Tabel. 1)

Berdasarkan analisis ragam interaksi menunjukan bahwa pemberian pupuk fosfat dan fungi mikoriza arbuskular berpengaruh tidak nyata $(\mathrm{P}>0,05)$ terhadap diameter batang. Hal ini diduga karena pemberian mikoriza ke dalam tanah sudah mampu menjalankan fungsinya secara optimal dalam membantu akar dalam penyerapan unsur hara terutama $\mathrm{P}$, walaupun pada analisis ragam interaksi tidak berpengaruh nyata. Hal ini dapat dilihat dari perkembangan akar dan bagian tajuk tanaman yang berkembang dengan baik. Fospat yang dapat diserap dimanfaatkan oleh tanaman dibawa ke bagian atas tanaman sebagai salah satu sumber reaksi biokimia dalam proses fotosintesis. Hasil fotosintesis dialokasikan pada bagian paling utama seperti daun dan cabang setelah itu baru pembentukan batang. Cambbell et al. (2002) bahwa hasil dari proses fotosintesis akan ditraslokasikan ke seluruh bagian tanaman yaitu daun, cabang, batang dan akar sehingga pertumbuhan pada pada masing - masing bagian tanaman meningkat.

\section{Jumlah Cabang (cabang)}

Hasil analisis ragam menunjukan bahwa pemberian pupuk fosfat dan fungi mikoriza arbuskular berpengaruh tidak nyata $(\mathrm{P}>0,05)$ terhadap parameter jumlah cabang (Tabel. 1)

Berdasarkan analisis sidik ragam interaksi pemberian pupuk fosfat dan fungi mikoriza arbuskular berpengaruh tidak nyata $(\mathrm{P}>0,05)$ terhadap jumlah cabang. Hal ini diduga karena jumlah cabang lebih dipengaruhi oleh faktor genetik dari tanaman Indigofera yang menyebabkan jumlah cabang relatif hampir sama. Dijelaskan oleh Martoyo (2001), bahwa respon pupuk terhadap jumlah cabang pada umumnya kurang memberikan gambaran yang jelas karena jumlah cabang mempunyai hubungan yang erat dengan faktor genetik. Ditambahkan oleh Sutejo dan Mulyani (1999), selain faktor genetik, pupuk fosfat yang bersifat slow release menyebabkan belum sepenuhnya dapat dimanfaatkan oleh tanaman untuk pertumbuhan dan perbanyakan cabang. 


\section{Jumlah Nodul (nodul)}

Hasil analisis ragam menunjukan bahwa pemberian pupuk fosfat dan fungi mikoriza arbuskular berpengaruh tidak nyata $(\mathrm{P}>0,05)$ terhadap parameter jumlah nodul (Tabel. 1).

Bedasarkan analisa ragam interaksi pemberian pupuk fosfat dan fungi mikoriza arbuskular berpengaruh tidak nyata $(\mathrm{P}>0,05)$ terhadap jumlah nodul. Hal ini diduga karena media tanam yang digunakan mengandung fraksi liat yang tinggi dengan dilakukannya penyiraman secara kontiyu menyebabkan porositas tanah menjadi rendah. Porosistas tanah yang rendah disebabkan oleh, rongga atau ruang pori yang terdapat didalam maupun diantara agregat tanah yang dapat diisi oleh air dan udara semakin kecil. Porosistas tanah yang rendah akan menganggu pertumbuhan dan efektifitas nodul pada akar tanaman, dimana proses pembentukan nodulasi terutama pada tanaman legum membutuhkan air dan udara. Penelitian ini juga tidak dilakukan pemberian inokulasi rhizobium sehinggga pembentukan nodul pada akar tanam tidak optimal. Dijelaskan oleh Buckman dan Brady (1974), tanah yang baik pada umumnya memiliki ketersediaan makanan bagi mikroba dan terpenting adalah ketersedian oksigen dan air, temperatur, konsentrasi ion $\mathrm{H}$ pada tanah dan faktor-faktor yang mempengaruhi pembentukan nodul akar dan fiksasi nitrogen pada tanaman legum adalah bakteri rhizobium, $\mathrm{pH}$ tanah, suhu, unsur N, P, K, Fe, Mo, dan senyawasenyawa penambatan $\mathrm{N}$, spesies tanaman dan tatalaksana umur pemotongan.

\section{KESIMPULAN}

Hasil penelitian dapat disimpulkan bahwa Pertumbuhan tanaman Indigofera zolligeriana yang diberi pupuk fosfat $\mathrm{P} 2$ : Pupuk SP-36 $\left(36 \% \mathrm{P}_{2} \mathrm{O}_{5}\right) \quad 150 \mathrm{~kg} / \mathrm{ha}$ dan Inokulasi 10 gr Mikoriza/polybag memberikan hasil terbaik pada parameter tinggi tanaman.

\section{DAFTAR PUSTAKA}

Agustina, 2004. Dasar Nutrisi Tanaman. Rineka Cipta. Jakarta.

Buchman, H.O. and N.C. Brady. 1974. The Nature and Propertises of Soil, $M c$ Millan Pub. Co. Inc: New York.

Campbell, N.A., J.B. Reece, L.G. and Mitchell, 2002, Biologi, Edisi kelima Jilid 1, Erlangga: Jakarta.

Gardner, F.P., R.B. Pearce, dan R.L. Mitchell. 1991. Fisiologi Tanaman Budidaya. UI Press: Jakarta.

Irdiana, I.Y. Sugito dan A. Soegianto. 2002 Pengaruh dosisi pupuk organik cair dan dosisi pupuk urea terhadap pertumbuhan hasil tanaman jagung manis (Zea mays saccharata ) Varietas bisi Sweet. Agrivita 24 ( 1 ) .

Lakitan, B. 2004. Dasar-Dasar Fisiologi Tumbuhan. PT. Raja Grafindo Persada: Jakarta.

Martoyo, K. 2001. Sifat Fisik Tanah Ultisol pada Penyebaran Akar 
Tanaman Kelapa Sawit. Warta PPKS.

Novizan. 2002. Petunjuk Pemupukan yang Efektif. Agromedia Pustaka: Jakarta

Nuhamara, S.T, 1994. Peranan Mikoriza untuk reklamasi lahan Kritis. Program Pelatihan Biologi dan Bioteknologi Mikoriza.

Niswati, A., S. G. Nugroho, M. Utomo, dan Suryadi. 1996. Pemamfaatan Mikoriza Vasikular Arbuskular untuk mengatasi Pertumbuhan Jagung Akibat Cekaman Kekeringan. Jurnal Ilmu Tanah Fakultas Pertanian: Universitas Lampung. No 3 Lampung.

Rao, N. dan S. Subha. 1994. Mikroorganisme tanah dan pertumbuhan tanaman. Edisi Kedua. Penerbit. Universitas Indonesia.

Sutejo dan M. Mulyani.1999. Pupuk dan cara pemupukan. Renika Cipta : Jakarta.

Simarmata, T. 2005, Revitalisasi Kesehatan Ekosistem Lahan Kritis dengan Memanfaatkan Pupuk Biologis Mikoriza dalam Percepatan Pengembangan Pertanian Ekologis di Indonesia, Seminar Nasional danWorkshop Cendawan Mikoriza, Universitas Jambi.

Tisdale, S. L. Nelson W. L. and Beatson. J.V 1985. Soil Fertility and Fertilits Macmillan Publishing. Co: New York 